UDK 35.072.6:366.542

https://doi.org/10.18485/union_pf_ccr.2021.ch7

Prof. dr Stevan Lilić ${ }^{*}$

Katarina Toskić**

\title{
INSPEKCIJSKI NADZOR I KOLEKTIVNA ZAŠTITA POTROŠAČA U UPRAVNOM POSTUPKU: STUDIJA PRIMERA NA SLUČAJU SUPERNOVA
}

\begin{abstract}
Apstrakt: Zaštita prava potrošača u Srbiji postaje ustavna kategorija 2006. godine, a zakoni o zaštiti potrošača koji su nakon toga usledili uvode nove institute i uređuju ovu oblast u skladu sa evropskim standardima. Međutim, problemi koji nastaju pri primeni individualnih mehanizama zaštite u potrošačkom kontekstu su izuzetno veliki broj transakcija relativno male vrednosti, odnosno vrednost pojedinačnog povređenog interesa po pravilu je toliko mala da, gledano iz ugla potrošača, ta vrednost ne opravdava pokretanje sudskog postupka koji bi mogao dugo da traje i puno da košta. Različiti mehanizmi zaštite kolektivnih potrošačkih prava $i$ interesa predstavljaju odgovor na pomenuti problem. Evropsko zakonodavstvo videlo je rešenje u kolektivnoj tužbi, koje se kroz praksu evropskih zemalja pokazalo kao efikasno. Međutim, uvođenjem kolektivne zaštite potrošača u upravnom postupku nakon odluke Ustavnog suda iz 2013. godine, kojom se postupak kolektivne zaštite $u$ potrošačkim sporovima pred sudom proglašava neustavnim, Srbija pravi značajno odstupanje. Slučaj Supernova ukazuje da kolektivna zaštita potrošača u upravnom postupku vodi neprepoznavanju povrede kolektivnog interesa potrošača od strane institucija, neujednačenoj praksi u skoro identičnim slučajevima i nedoslednosti primene donetih akata. Kolektivna zaštita potrošača preneta iz nadležnosti suda na organe uprave pokazala je da oni nemaju kapacitete da odgovore na ovaj zadatak.
\end{abstract}

Ključne reči: upravni nadzor, inspekcijski postupak, zaštita potrošača, kolektivna zaštita potrošača, slučaj Supernova.

\section{UPRAVNI NADZOR}

\subsection{POJAM}

Nadzor (kontrola) predstavlja odnos dva subjekta u kojem tzv. aktivni subjekt, koji vrši nadzor, kontroliše rad tzv. pasivnog subjekta nad kojim se nadzor vrši. Bitna karakteristika nadzora je sistematsko posmatranje i ocenjivanje rada drugog subjekta, na osnovu unapred utvrđenih merila, uz mogućnost da aktivni subjekt utiče na budući rad pasivnog subjekta. ${ }^{1}$

* Redovni profesor univerziteta (www.slilic.com).

** Diplomirani pravnik, YUCOM (www.yucom.org.rs)

1 Uporedi: Dimitrijević, P., 1983, Osnovi upravnog prava, Beograd, str. 273-276. 
Upravni nadzor je poseban oblik vršenja upravne delatnosti u kojem do izražaja dolaze ovlašćenja upravnog karaktera. Sa teorijskopravnog stanovišta, upravni nadzor $\mathrm{u}$ formalnom smislu polazi od vršioca upravnog nadzora i predstavlja nadzor koji vrše ovlašćeni državni organi uprave. S druge strane, upravni nadzor u materijalnom smislu polazi od nadzornih ovlašćenja kojima se nadzor vrši i predstavlja nadzor koji se vrši prema načelima i pravilima opšteg ili posebnog upravnog (npr. inspekcijskog) postupka upravnim ovlašćenjima. ${ }^{2}$

U našem pravnom sistemu opšta pitanja nadzora, kao i pitanja nadzornih ovlašćenja organa državne uprave regulisana su Zakonom o državnoj upravi. ${ }^{3}$ U tom kontekstu, jedan od oblika upravnog nadzora je inspekcijski nadzor (član 18): „Inspekcijskim nadzorom organi državne uprave ispituju sprovođenje zakona i drugih propisa neposrednim uvidom u poslovanje i postupanje fizičkih i pravnih lica i, zavisno od rezultata nadzora, izriču mere na koje su ovlašćeni. Inspekcijski nadzor uređuje se posebnim zakonom." Taj posebni zakon koji predviđa Zakon o državnoj upravi je Zakon o inspekcijskom nadzoru. ${ }^{4}$

\subsection{INSPEKCIJSKI NADZOR}

Pojam i cilj inspekcijskog nadzora definisani su Zakonom o inspekcijskom nadzoru (član 2): „Inspekcijski nadzor je posao državne uprave čija sadržina i pojam su utvrđeni zakonom kojim se uređuje rad državne uprave, koga vrše organi državne uprave, organi autonomne pokrajine i organi jedinica lokalne samouprave, $s$ ciljem da se preventivnim delovanjem ili nalaganjem mera obezbedi zakonitost i bezbednost poslovanja i postupanja nadziranih subjekata i spreče ili otklone štetne posledice po zakonom i drugim propisom zaštićena dobra, prava $\mathrm{i}$ interese. Inspekcijskom nadzoru upodobljavaju se drugi oblici nadzora i kontrole čijim vršenjem se ispituje primena zakona i drugih propisa neposrednim uvidom u poslovanje i postupanje nadziranog subjekta, koje vrše državni organi i drugi subjekti sa javnim ovlašćenjima, u skladu sa posebnim zakonom.“

U stručnim radovima se ističe da je inspekcijski nadzor „posebna vrsta upravnog nadzora koji se ostvaruje neposrednim uvidom u odgovarajuće pravne i faktičke situacije". Cilj inspekcijskog nadzora je kako kontrola primene zakona od građana i pravnih lica tako i kontrola primene zakona od samih organa uprave. Inspekcijskim nadzorom organi državne uprave ispituju sprovođenje zakona i drugih propisa neposrednim uvidom u poslovanje i postupanje fizičkih i pravnih lica i, zavisno od rezultata nadzora, izriču mere na koje su ovlašćeni. ${ }^{5}$

Organizaciono, inspekcijski nadzor obavljaju posebni organi uprave (inspektorati), koji su najčešće u sastavu nekog drugog organa uprave (ministarstva). Operativno, inspekcijski nadzor obavljaju posebno ovlašćena službena lica

2 Uporedi: Lilić, S., 2014, Upravno pravo / Upravno procesno pravo, 8. izdanje, Beograd, Pravni fakultet Univerziteta u Beogradu, str. 318-331.

3 Zakon o državnoj upravi, Sl. glasnik RS, br. 79/05, 101/07, 95/10, 99/14, 47/18, 30/2018.

4 Zakon o inspekcijskom nadzoru, Sl. glasnik RS, br. 36/15, 44/18, 95/18.

5 Uporedi: Blažić, Đ., 1995, Prilog teoriji o inspekcijskom nadzoru, Pravni život, 9; Blažić, Đ., 1996, Inspekcijski nadzor kao oblik upravno pravne zaštite građana, Pravni život, 9. 
(inspektori) u posebno propisanom postupku (inspekcijski postupak). Postoje brojne inspekcije, kao i brojni zakonski i drugi propisi koji na odgovarajući način regulišu organizaciju i rad inspekcija od kojih je najznačajniji Zakon o ministarstvima, prema kojem su nadležnost i inspekcijska ovlašćenja za oblast zaštite potrošača poverena Ministarstvu trgovine, turizma i telekomunikacija koje (član 8. stav 1): „obavlja poslove državne uprave koji se odnose na: funkcionisanje tržišta; strategiju i politiku razvoja trgovine; unutrašnju trgovinu; promet robe i usluga; [...] zaštitu potrošača; [...] inspekcijski nadzor u oblasti trgovine, kao i druge poslove određene zakonom. ${ }^{\text {"6 }}$

\subsection{POSTUPAK INSPEKCIJSKOG NADZORA}

Zakonom o inspekcijskom nadzoru uređuju se sadržina, vrste i oblici i postupak inspekcijskog nadzora, ovlašćenja i obaveze učesnika u inspekcijskom nadzoru i druga pitanja od značaja za inspekcijski nadzor (član 1).

Prema ovom zakonu (član 18): „Postupak inspekcijskog nadzora pokreće se i vodi po službenoj dužnosti ili zahtevom nadziranog subjekta za vršenje inspekcijskog nadzora, kao i zahtevom drugog lica kome je posebnim zakonom priznato svojstvo stranke u postupku. Kod ocene o postojanju razloga za pokretanje postupka po službenoj dužnosti inspektor uzima u obzir predstavke, kao i upozorenja nadležnih organa. Predstavke imaju dejstvo inicijative za pokretanje postupka, a podnosioci tih inicijativa nemaju svojstvo stranke u postupku koji se može pokrenuti na osnovu te inicijative. [...] Inspektor neće pokrenuti postupak po službenoj dužnosti na osnovu predstavke ako je procenjen neznatan rizik ili je posredi zloupotreba prava. [...] Inspekcijski nadzor počinje kad inspektor uruči nadziranom subjektu, odnosno prisutnom licu nalog za inspekcijski nadzor.“

Inspektor sačinjava zapisnik o inspekcijskom nadzoru (član 35) koji se dostavlja nadziranom subjektu u roku od osam dana od završetka inspekcijskog nadzora, s tim da ovlašćeno lice nadziranog subjekta može da odbije da primi zapisnik, što inspektor konstatuje u pisanom obliku i u zapisniku navodi razloge zbog kojih je prijem zapisnika odbijen. Nadzirani subjekat ima pravo da u pisanom obliku stavi primedbe na zapisnik o inspekcijskom nadzoru (član 36), u roku od pet radnih dana od njegovog prijema. Postupajući po primedbama na zapisnik, inspektor može da izmeni predloženu ili naloženu, odnosno izrečenu meru, ili da odustane od nje.

Rešenjem inspektor odlučuje o merama upravljenim prema nadziranom subjektu (član 37). Ako inspektor u vršenju inspekcijskog nadzora ne utvrdi nezakonitosti, nepravilnosti ili nedostatke, on ne donosi rešenje ili zaključak i tada okončava postupak inspekcijskog nadzora dostavljanjem nadziranom subjektu zapisnika u kome se navodi da nisu utvrđene nezakonitosti, nepravilnosti ili nedostaci u njegovom poslovanju ili postupanju. Ako inspektor ne donese rešenje po isteku dana okončanja inspekcijskog nadzora određenog u nalogu za inspekcijski nadzor (član 38), odnosno po isteku zakonskog roka za donošenje rešenja, nadzirani subjekat može zahtevati da inspektor okonča postupak. Ako inspektor

Zakon o ministarstvima, Sl. glasnik RS, br. 44/14, 14/15, 54/15, 96/15, 62/17. 
to ne učini u roku od osam dana od dana podnošenja zahteva, smatra se da je postupak obustavljen i da nisu pronađene nezakonitosti u poslovanju i postupanju nadziranog subjekta.

Protiv rešenja inspektora može se izjaviti žalba (član 38) u roku od 15 dana od dana dostave pisanog rešenja. Žalba odlaže izvršenje rešenja. U slučaju da je prvostepena odluka inspektora već jedanput bila poništena, drugostepeni organ ne može je opet poništiti i uputiti predmet inspekciji na ponovni postupak, nego će sam rešiti ovu upravnu stvar. Odluka drugostepenog organa po žalbi je konačna i protiv nje se može pokrenuti upravni spor (član 40), u skladu sa zakonom kojim se uređuju upravni sporovi.

\subsection{INSPEKCIJSKI POSTUPAK I UPRAVNI POSTUPAK}

U vezi sa vršenjem inspekcijskog nadzora posebno je značajna odredba Zakona o inspekcijskom nadzoru kojom je propisano da „u postupku vršenja inspekcijskog nadzora, inspektor [...] postupa saglasno načelima i pravilima postupka kojima je uređen opšti upravni postupak“ (član 4. stav 2).

Ovakva formulacija Zakona o inspekcijskom nadzoru upućuje na zaključak da postoji poseban procesni odnos između Zakona o inspekcijskom nadzoru i zakona koji sadrži „načela i pravila postupka koja uređuju opšti upravni postupak“. U konkretnom slučaju radi se o Zakonu o opštem upravnom postupku. ${ }^{7}$

U zakonodavnoj praksi i stručnim analizama za ovakav međusobni odnos između „posebnog“ i „opšteg“ kaže se da počiva na načelu lex specialis. Polazeći od odredbe člana 4. stav 2. Zakona o inspekcijskom nadzoru, postupak inspekcijskog nadzora predstavljao bi „poseban upravni postupak“ u odnosu na „opšti upravni postupak“ koji je propisan Zakonom o opštem upravnom postupku. Druga strana načela lex specialis je načelo supsidijarne (dopunske) primene pravila opšteg upravnog postupka u situacijama kada posebnim zakonom pojedina pitanja postupka nisu normirana.

Polazeći od toga, u kontekstu inspekcijskog nadzora može se reći da je inspekcijski postupak „poseban upravni postupak“ koji je istovremeno, sa jedne strane regulisan Zakonom o inspekcijskom nadzoru, a sa druge i Zakonom o opštem upravnom postupku (član 3): „Ovaj zakon primenjuje se na postupanje u svim upravnim stvarima. Pojedina pitanja upravnog postupka mogu posebnim zakonom da se urede samo ako je to u pojedinim upravnim oblastima neophodno, ako je to u saglasnosti sa osnovnim načelima određenim ovim zakonom i ne smanjuje nivo zaštite prava i pravnih interesa stranaka zajemčenih ovim zakonom."

Međutim, odnos opšteg i posebnih upravnih postupaka može dovesti do veoma komplikovanih, čak i protivrečnih situacija u kojima nije uvek najjasnije koja se pravila postupka imaju primeniti. ${ }^{8}$ Ovakve situacije velikim delom proi-

7 Zakon o opštem upravnom postupku, Sl. glasnik RS, br. 18/16, 95/18.

8 Uporedi: Lilić, S., 2019, Zakon o opštem upravnom postupku - Anatomija zakonskog projekta, Beograd, Dosije, str. 21-22. 
stiču iz okolnosti da je (nov) Zakon o opštem upravnom postupku usvojen 2016. godine, tj. nakon stupanja na snagu Zakona o inspekcijskom nadzoru koji je pitanja odnosa inspekcijskog postupka, kao posebnog upravnog postupka, regulisao u skladu sa Zakonom o opštem upravnom postupku iz 1997. godine ${ }^{9}$ koji je bio na snazi u vreme usvajanja Zakona o inspekcijskom nadzoru. Nov ZUP radikalno odstupa od ključnih brojnih formulacija u ranijem ZUP-u (npr. bitno drugačija definicija „upravne stvari“), zbog čega su se u praktičnoj primeni otvorila brojna sporna pitanja (npr. u vezi sa upravnim ugovorima, garantnim aktom, prigovorom i dr.). ${ }^{10}$

U konkretnom slučaju odnosa između postupka inspekcijskog nadzora, kao „posebnog upravnog postupka“ sa jedne, i pravila opšteg upravnog postupka, sa druge strane, odmah se može uočiti „strukturalni defekt" odredbe člana 3. ZUP-a. Tako, naslov (rubrum) člana 3. ZUP-a glasi: „Opšti i poseban upravni postupak“. Međutim, ovaj naslov je neadekvatan jer se u tekstu odredbe člana 3. uopšte ne spominje upravni postupak (ni opšti, ni poseban). Osim toga, formulacije stavova u ovom članu su protivrečne jer tekst stava 1. isključuje svako odstupanje od pravila ZUP-a (u bilo kom drugom upravnom postupanju), dok se istovremeno na osnovu teksta stava 2. može zaključiti da je odstupanje „ipak“ moguće. ${ }^{11}$

\section{ZAŠTITA PRAVA POTROŠAČA}

\subsection{PRAVNI POLOŽAJ I NEJEDNAKOST POTROŠAČA}

U situacijama kada potrošači nemaju delotvornu zaštitu vansudskim mehanizmima, čak i nesumnjive povrede prava potrošača i pretrpljene štete većinom ne dobijaju epilog u građanskim postupcima, delom zbog trajanja i troškova sudskog postupka, delom zbog štete koja nije dovoljno velika da bi ulaganje vremena i novca bilo prihvatljivo, što je dovelo do osnivanja organizacija za zaštitu potrošača i izdavanja posebnih publikacija. ${ }^{12}$

Nedovoljno regulisani odnos pružaoca usluga i dobara sa podređenim položajem kupaca postao je posebno evidentan u poslednjih nekoliko decenija. Kupac u ovom odnosu predstavlja slabiju stranu u pravnom poslu, shodno kriterijumima ekonomske snage, znanja i iskustva i informacija koje su mu na raspolaganju. Razlozi za sve značajnije pogoršanje ovog odnosa na štetu kupca

9 Zakon o opštem upravnom postupku, Sl. list SRJ, br. 33/97, 31/01; Sl. glasnik RS, br. 30/10.

10 Uporedi: Lilić, S., Manojlović, A., Golubović, K., 2018, Priručnik za praktičnu primenu novog ZUP-a - Sporna pitanja i odgovori, Beograd, Službeni glasnik.

11 Lilić, S., 2019, str. 23.

12 Nacionalna organizacija potrošača Srbije, 2018. Vodič kroz kolektivnu zaštitu. Takođe: YUCOM, 2019, Vodič za zaštitu prava potrošača, str. 7: „Vodič [...] je publikacija koja na što jednostavniji i praktičan način treba da predstavi građanima i građankama kojim su zakonom zaštićeni kao potrošači, koja su njihova prava, šta je reklamacija, koja je uloga tržišne inspekcije, šta podrazumeva sudska zaštita, koja je uloga potrošačkih organizacija, uključujući i kontakte potrošačkih savetovališta." 
pre svega su posledica globalizacije trgovine, ukrupnjavanja kapitala kompanija koje se bave prodajom dobara ili pružanjem usluga, i rasta broja proizvoda i usluga sa razvojem potrošačkog društva. Potrošač, kao slabija strana, treba da se zaštiti od nepoštenog poslovanja i zloupotrebe pregovaračke snage druge strane u pravnom poslu. Ovo podrazumeva mogućnost da stvarno pregovara i utiče na sadržinu kupoprodajnog ugovora, da ima pravo i mogućnost izbora i da poseduje dovoljnu pravnu zaštitu u odnosima sa trgovačkim preduzećima, javnim komunalnim kompanijama, turističkim agencijama, bankama i drugim finansijskim institucijama, kao i drugim subjektima ponude. ${ }^{13}$

\subsection{MEĐUNARODNE REAKCIJE NA ODNOS POTROŠAČA I TRGOVCA}

Jedna od prvih značajnih međunarodnih reakcija na produbljivanje nejednakosti u odnosu potrošača i trgovca usledila je 1975. godine kada su evropske države, potpisnice Ugovora o osnivanju Evropske zajednice (tzv. Rimskog ugovora iz 1957. godine), donele Evropsku povelju o obaveštavanju i zaštiti potrošača ${ }^{14}$ koja, između ostalog, predviđa pravo na pravnu zaštitu potrošača, prava na obaveštavanje i edukaciju potrošača, kao i prava na udruživanje sa svrhom zaštite interesa potrošača, kao i prava na predstavljanje u organima koji odlučuju o stvarima od interesa za potrošače. Evropska komisija je dve godine kasnije usvojila „prvi preliminarni program Evropske ekonomske zajednice o zaštiti potrošača i politici obaveštenosti“ koji je postavio temelje razvoja prava zaštite potrošača Evropske unije. Kako se ističe, četrdeset pet godina nakon usvajanja ovog dokumenta, zaštita potrošača predstavlja jednu zasebnu i vrlo razvijenu i dinamičnu oblast prava EU koja je osnova za usklađeno delovanje svih nacionalnih tela, vladinih i nevladinih organizacija država članica EU. ${ }^{15}$

Značajan korak ka zaštiti prava potrošača predstavlja Rezolucija 39/248 Generalne skupštine Ujedinjenih nacija iz 1985. godine ${ }^{16}$ kojom se predlažu „smernice za zaštitu potrošača" kako bi se podstakle države da normativno urede ovu oblast. Smernice Rezolucije odnosile su se i na razvoj institucija koje bi potrošače obaveštavale i podučavale o njihovim pravima, te delotvorno štitile njihova prava. Do trenutka donošenja posebnog nacionalnog zakona koji uređuje potrošačko pravo, postojeći sistem zaštite svodio se pre svega na ugovorno pravo koje, kako se pokazalo, nije moglo da odgovori na izazove koje su donosili ekonomski i industrijski razvoj, a u kome je potrošač imao bitnu ulogu.

13 Madžar, L., 2010, Politika zaštite potrošača u Srbiji sa aspekta politike zaštite potrošača u zemljama EU, Škola biznisa, 4, str. 58.

14 Uporedi: Commission of the European Communities, Consumer Protection Information and Policy - Third Report, October 1980, (http://aei.pitt.edu/3103/1/3103.pdf).

15 Lazarević, N. et al., 2013, Studija potrošačke politike u Srbiji ka evropskom nivou zaštite potrošača u Srbiji, Beograd, Centar za evropske politike, str. 1-5.

16 UN General Assembly, UN doc A/RES/39/248, (1984-1985). Takođe: Matić, M., 2013, Analiza zakona o zaštiti potrošača, Beograd, EU Support to the Office for Cooperation with Civil Society, str. 3. 


\section{NORMATVNI OKVIR ZAŠTITE POTROŠAČA U SRBIJI}

\subsection{USTAVNI OKVIR ZAŠTITE POTROŠAČA}

Ustavom Srbije iz 2006. godine zaštita potrošača postaje ustavna kategorija. Tako, prema članu 90. Ustava: „Republika Srbija štiti potrošače. Posebno su zabranjene radnje usmerene protiv zdravlja, bezbednosti i privatnosti potrošača, kao i sve nečasne radnje na tržištu. "17 Zakoni o zaštiti potrošača koji su nakon toga usledili uvode nove institute i mehanizme zaštite potrošača, predviđaju postojanje i jačaju ulogu organizacija za zaštitu potrošača i time ovu oblast usklađuju sa evropskim zakonodavstvom, sve u sklopu procesa harmonizacije sa evropskim acquis communautaire.

Do danas u Srbiji je bilo nekoliko zakona o zaštiti potrošača koji su zasnovani na osnovnim načelima uspostavljenim od strane Evropske unije i Ujedinjenih nacija. Zanimljiva okolnost je da je u Srbiji usvojen Zakon o zaštiti potrošača 2010. godine, ali da je ubrzo bio zamenjen novim - Zakonom o zaštiti potrošača iz 2014. godine kojim je zaštita kolektivnih interesa potrošača iz nadležnosti sudova preneta u nadležnost resornog ministarstva (trgovine). Međutim, ocena statusa potrošačkog društva u Srbiji i izveštaji o napretku Srbije u procesu pristupanja EU govore da ipak sveobuhvatni normativni deo zaštite prava ne dovodi do potpune implementacije i poštovanja prava potrošača.

Pravna sigurnost potrošača podrazumeva više od normativnog zakonskog okvira koji propisuje prava i obaveze. Ona podrazumeva i stvaranje okruženja u kojem postoji svest $\mathrm{o}$ obaveznosti poštovanja prava potrošača, delotvornu zaštitu koja podrazumeva dostupna i efikasna pravna sredstva, kao i odgovarajuću naknadu štete. ${ }^{18}$

\subsection{ZAKONSKI OKVIRI ZAŠTITE POTROŠAČA}

Prvi zakon o zaštiti potrošača na našim prostorima donet je u Saveznoj Republici Jugoslaviji 2002. godine sa ciljem utvrđivanja prava potrošača i načina ostvarivanja tih prava. ${ }^{19}$ Osim osnovnih prava potrošača, koja predstavljaju tada već zvanična načela i osnovna prava potrošača u svetu, udruženja potrošača i organa za zaštitu potrošača, ovaj zakon predvideo je i inspekcijski nadzor i upravne mere, imovinsku zaštitu u parničnom postupku i mogućnost vansudskog rešavanja sporova.

Prema ovom zakonu (čl. 44-49), inspekcijski nadzor podrazumevao je nadzor organa nadležnog za poslove tržišne inspekcije nad poštovanjem zakona od strane trgovaca. Za nepostupanje trgovaca po reklamaciji potrošača, savezni organ nadležan za poslove tržišne inspekcije bio je ovlašćen da donese rešenje kojim će tom preduzeću, ili drugom pravnom licu ili preduzetniku,

17 Ustav Republike Srbije, Sl. glasnik RS, br. 98/06.

18 Madžar, L., 2010, str. 55-56.

19 Zakon o zaštiti potrošača, Sl. list SRJ, br. 37/02. 
narediti da ispuni zahtev potrošača. Osim rešenja kojim se naređuje postupanje po reklamaciji, organ nadležan za poslove tržišne inspekcije imao je i ovlašćenja da donese rešenje kojim zabranjuje prodaju proizvoda ili pružanje usluga privrednom društvu ili preduzetniku u propisanim situacijama, ali i da donese rešenje kojim zabranjuje reklamiranje proizvoda ili pružanja usluga u slučajevima kada se reklamiranjem vrše nedozvoljene radnje (npr. diskriminiše određena grupa).

Donošenjem Zakona o zaštiti potrošača Srbije 2005. godine, raniji savezni zakon prestaje da važi. ${ }^{20}$ Novim republičkim zakonom uređuju se, između ostalog, osnovna prava potrošača, način ostvarivanja tih prava, zaštita prava potrošača i primena etičkih načela. Zakon u delu nadzora jasno ističe da (čl. 71-76) nadzor nad primenom ovog zakona vrši nadležno ministarstvo trgovine, a inspekcijski nadzor vrši nekoliko ministarstava (ministarstvo nadležno za poslove zdravlja, ministarstvo nadležno za poslove poljoprivrede, vodoprivrede i šumarstva, ministarstvo nadležno za poslove energetike) preko svojih inspekcija, te nadležni organi lokalne samouprave preko komunalnih inspekcija.

U slučaju nepostupanja trgovca po reklamaciji, za razliku od ranijeg zakona, inspektor je na osnovu Zakona iz 2005. godine mogao doneti rešenje kojim će (čl. 74) prodavcu naložiti da ispuni zahtev potrošača, ali i odrediti način ispunjenja zahteva i rok za postupanje, koji ne može biti duži od 30 dana od dana kada je rešenje postalo konačno.

Dodatno, ovim zakonom osnažuje se preventivna uloga (član 75), pa inspektor $\mathrm{u}$ vršenju nadzora proverava da li roba ili usluge imaju određene nedostatke poput proizvoda koji nemaju deklaraciju, uputstvo za korišćenje, proizvoda za decu koji su izrađeni od neadekvatnih materijala ili predstavljaju opasnost po bezbednost i zdravlje i slično. U tim situacijama, inspektor je ovlašćen da donese rešenje kojim će odrediti rok u kome je prodavac ili davalac usluga dužan da otkloni utvrđeni nedostatak. Ako prodavac ili davalac usluga ne otkloni utvrđeni nedostatak u roku koji je određen u rešenju inspektora, inspektor će doneti rešenje o zabrani prodaje proizvoda, odnosno pružanja usluga.

\subsection{ZAKON O ZAŠTITI POTROŠAČA IZ 2010. GODINE}

Sledeći napor ka poboljšanju položaja potrošača je donošenje novog Zakona o zaštiti potrošača koji je usvojen 2010. godine i predstavlja primetan napredak u odnosu na ranije zakone. ${ }^{21}$ Krupan korak koji vodi ka većoj pravnoj sigurnosti učinjen je uvođenjem daleko većeg stepena informisanosti potrošača o karakteristikama proizvoda (član 22) tako što je uvedena obaveza prodavaca ili pružaoca usluga da pruže kompletne informacije o proizvodu/usluzi. U slučaju reklamacija, ovaj zakon predvideo je da je teret dokazivanja na trgovcima (proizvođačima, odnosno pružaocima usluga). Formalno gledano, Zakon iz 2010. godine išao je

20 Zakon o zaštiti potrošača, Sl. glasnik RS, br. 79/05.

21 Zakon o zaštiti potrošača, Sl. glasnik RS, br. 73/10. 
u korak sa evropskim standardima, posebno što je sadržao 15 najvažnijih i najnovijih direktiva Evropske unije u toj oblasti (npr. Direktiva 2011/83/Eu o potrošačkim pravima - Directive 2011/83/Eu on consumer rights). ${ }^{22}$ Kada je u pitanju strategija zaštite potrošača, ona je obuhvatila precizno definisane nadležnosti resornog ministarstva, zaštitu potrošača na lokalnom nivou, kao i praćenje tržišta i inspekcijski nadzor. Međutim, iako je ovaj zakon imao formalna svojstva, sam čin usvajanja zakona nije bio dovoljan s obzirom na to da je izostala njegova dosledna implementacija.

Za nadzor nad primenom ovog zakona nadležna su bila različita ministarstva. Ministarstva u vršenju nadzora međusobno sarađuju, odnosno međusobno se obaveštavaju o preduzetim merama, razmenjuju informacije, pružaju neposrednu pomoć i preduzimaju zajedničke mere i aktivnosti značajne za sprovođenje inspekcijskog nadzora.

Jedna od uočenih karakteristika Zakona iz 2010. godine je izostanak ovlašćenja Ministarstva trgovine, odnosno tržišne inspekcije da rešava reklamacije potrošača u smislu dosadašnjeg postupanja, odnosno da utvrđuje osnovanost podnete reklamacije i da rešenjem nalaže trgovcu da potrošaču zameni kupljenu robu za novu robu, odnosno robu odgovarajuće marke (modela, tipa), ili da mu se vrati iznos plaćen za tu robu u visini maloprodajne cene te robe na dan vraćanja, ili otklanjanje nedostatka na robi o trošku prodavca. Ista je situacija i u pogledu reklamacije na pruženu uslugu zbog nedostatka u izvršenju određene usluge.

Prema tada novom Zakonu iz 2010. godine, ovlašćenja tržišne inspekcije u pogledu reklamacije potrošača svela su se na proveravanje da li trgovac odgovara potrošaču na reklamaciju bez odlaganja sa izjašnjenjem o podnetom zahtevu i predlogom njegovog rešavanja, te da ukoliko trgovac to nije učinio, nadležni inspektor je rešenjem određivao rok u kome je trgovac (prodavac ili davalac usluga) dužan da odgovori potrošaču. Ukoliko trgovac nije postupio po prethodnom rešenju, nadležni inspektor bio je ovlašćen da trgovcu privremeno zabrani prodaju robe, odnosno pružanje usluga do otklanjanja tog nedostatka zbog kojeg je ta mera izrečena. Nadležni inspektor bio je ovlašćen i da podnese prekršajnom sudu zahtev za pokretanje prekršajnog postupka ukoliko trgovac ne odgovori potrošaču u propisanom roku i ne izjasni se o podnetom zahtevu i ne predloži njegovo rešavanje.

Zakon iz 2010. godine u načelu je predstavljao značajan napredak ka jačanju prava potrošača. Takođe, zakon i predviđeni mehanizmi njegovog sprovođenja bili su u velikoj meri u skladu sa zakonima u razvijenim zemljama Evropske unije. Međutim, institucije koje su u vreme važenja ovog zakona postojale u Srbiji i njihova efikasnost nisu mogle da odgovore na zahteve zakona. Zaštita putem sudova pokazala se kao neefikasna, dok su vansudski mehanizmi stagnirali. Nedostatak dovoljnog broja i kapaciteta potrošačkih organizacija, koje su jedna od novina u sistemu zaštite, takođe je bio evidentan. 


\subsection{ZAKON O ZAŠTITI POTROŠAČA IZ 2014. GODINE}

Sadašnji Zakon o zaštiti potrošača usvojen je 2014. godine i formalno je ojačao i olakšao položaj potrošača (npr. ukidanje sudskih taksi za potrošačke sporove do određenog iznosa) predvidevši, između ostalog, i nekoliko koraka i potencijalnih načina zaštite potrošača koji prethode sudskom postupku, sa ciljem da do njega i ne dođe. ${ }^{23}$ Novine u pogledu inspekcijskog nadzora vidne su u delu propisivanja samog postupka inspekcijskog nadzora, kao i preciziranja rokova koji su u prethodnom zakonu ostavljeni proceni inspekcije.

Imajući u vidu činjenicu da inspekcije, u skladu sa Zakonom o inspekcijskom nadzoru, pre svega treba da imaju preventivnu funkciju, osnovno merilo za vrednovanje rada inspekcija treba da bude efikasnost u sprečavanju nastanka negativnih posledica nezakonitosti i nepravilnosti u radu (preventivna uloga), kao i usklađena i dosledna praksa inspekcija, koja bi u konačnosti dala rezultate $\mathrm{u}$ vidu ispravljenih nepravilnosti i nezakonitosti u daljem poslovanju (korektivna uloga). Dodatno, uz institut kolektivne zaštite interesa potrošača koji se od 2015. godine sprovodi kroz upravni postupak, uloga inspekcije postaje transparentnija i izazovnija, s obzirom na to da ovaj institut najčešće pogađa trgovce koji imaju dominantan položaj na tržištu, te je uloga inspekcije da se direktno suprotstavi ponašanju najsnažnijih aktera na tržištu.

\section{KOLEKTIVNA ZAŠTITA POTROŠAČA}

Kako se u stručnim radovima ističe, mehanizmi zaštite zakonom garantovanih prava potrošača su brojni i u literaturi se obično razvrstavaju na javnopravne i privatnopravne. U prve spada vansudska zaštita u upravnom postupku i sudska zaštita pred prekršajnim, upravnim i krivičnim sudovima, a u druge sudska zaštita u opštem parničnom postupku i u posebnim parničnim postupcima za zaštitu individualnih i kolektivnih potrošačkih prava i interesa, kao i različiti mehanizmi vansudskog rešavanja potrošačkih sporova. Uz to postoje i mehanizmi samouređivanja, to jest samoregulacije trgovaca u okviru njihovih komora, udruženja i saveza. Mehanizmi pravne zaštite potrošača mogu da se podele i na mehanizme individualne i kolektivne zaštite. U prvom slučaju reč je o zaštiti subjektivnog prava potrošača, koju on može da ostvaruje u opštem parničnom postupku ili u posebnim parničnim postupcima. U drugom slučaju reč je o različitim mehanizmima pravne zaštite kolektivnih potrošačkih interesa u upravnom ili parničnom postupku. ${ }^{24}$

Različiti mehanizmi kolektivne zaštite potrošača, to jest zaštite kolektivnih potrošačkih prava i pravom priznatih interesa, predstavljaju odgovor na praktične probleme koji nastaju pri primeni individualnih mehanizama zaštite u potrošačkom kontekstu. Specifičnost tog konteksta jeste izuzetno veliki broj transakcija relativno male vrednosti: potrošačka roba se masovno proizvodi, stavlja se u promet u ogromnom broju pojedinačnih transakcija i, potom, masovno kori-

23 Zakon o zaštiti potrošača, Sl. glasnik RS, br. 62/14, 6/16, 44/18.

24 Uporedi: Karanikić Mirić, M., 2014, Kolektivna zaštita potrošača u srpskom pravu, Zbornik radova Perspektive implementacije evropskih standarda u pravni sistem Srbije, Knjiga 4, Beograd, Pravni fakultet Univerziteta u Beogradu, str. 166. 
sti, odnosno troši. Isto se može kazati za potrošačke usluge. To znači da postoji veoma mnogo pojedinačnih situacija u kojima veliki broj pojedinačnih interesa može da bude povređen. Međutim, vrednost pojedinačnog povređenog interesa po pravilu je toliko mala da, gledano iz ugla potrošača, ta vrednost ne opravdava pokretanje sudskog postupka koji bi mogao dugo da traje i puno da košta. To dalje znači da trgovac može da se pouzda u 'potrošačku apatiju', to jest u to što potrošač po pravilu neće pokrenuti sudski postupak za zaštitu svog subjektivnog prava ukoliko je vrednost spora relativno mala. ${ }^{25}$

Ovakva pravna situacija ostavlja potrošače da trpe povrede, dok posredno ohrabruje trgovce ka nepoštenoj poslovnoj praksi i drugim oblicima ponašanja koje vode povredi prava potrošača. Osim navedenog, ovakva praksa nameće nejednake tržišne uslove za one trgovce koji se pridržavaju pravila, te ne postoji adekvatno odvraćanje od nepoštene poslovne prakse. ${ }^{26}$

Kako je istaknuto, u rešavanju pomenutog problema, evropsko zakonodavstvo videlo je rešenje u kolektivnoj zaštiti potrošača kao načinu zaštite koji je prilagođen specifičnom položaju potrošača. U Srbiji institut kolektivne zaštite bio je predviđen Zakonom o parničnom postupku u vreme važenja Zakona o zaštiti potrošača iz 2010. godine i sprovodio se pred redovnim sudovima u građanskim parnicama. Predstavljao je mogućnost da organizacije potrošača i druga udruženja i savezi kao aktivno legitimisani u postupku kolektivne zaštite potrošača pokrenu postupak pred sudom, dok bi svaki pojedinac koji je oštećen na isti način i od strane istog trgovca mogao da pristupi na strani tužioca u svojstvu umešača sa položajem jedinstvenog suparničara. Na ovaj način težilo se motivisanju oštećenih potrošača da se pridruže postupku i time se pre svega uticalo na smanjenje pomenutih negativnih efekata. ${ }^{27}$

Međutim, Ustavni sud Republike Srbije je 2013. godine proglasio odredbe Zakona o parničnom postupku koje se odnose na kolektivnu zaštitu neustavnim, ističući da zakonom nije uređeno kada jedan građanskopravni spor ima karakter spora o kolektivnim pravima koji bi se rešavao po pravilima posebnog postupka, te da nema ni upućujuće norme iz koje bi se utvrdilo na koje se sporove ove odredbe odnose, odnosno nije propisano koji se spor, u smislu ovih odredaba, smatra sporom o kolektivnim pravima, niti je regulisan pojam kolektivnih prava i interesa. ${ }^{28}$ Nasuprot tome, u uporednom pravu kolektivno obraćanje sudu je retko eksplicite definisano, ${ }^{29}$ (npr. nemački Unterlassungsklagegesetz, kao ni

25 Ibid., str. 167.

26 Uporedi: Božović, B., 2016, Stručna analiza Zaštita potrošača u evropskom pravu i u praksi medunarodnih i nacionalnih sudova, Podgorica, Centar za monitoring i istraživanje, (http:// cemi.org.me/wp-content/uploads/2017/03/Strucna-analiza-Zastita-potrosaca-u-evropskompravu.pdf).

27 Bodiroga, N., 2013, Komentar Odluke Ustavnog suda Iuz-51/2012 o neustavnosti glave 36. Zakona o parničnom postupku: Postupak za zaštitu kolektivnih prava i interesa proglašen neustavnim i time onemogućeno udruženjima ostvarivanje prava na pristup sudu, Beograd, Ustavno-sudski informator, 2014/1.

28 Uporedi: Ustavni sud, Ocenjivanje ustavnosti ili zakonitosti opštih akata, Presuda od 23. 5. 2013, IUz-51/2012.

29 Uporedi: Jovanovic-Zattila, M., Vukadinovic, R., Collective Redress in Consumer Protection in Serbia, in: Efremova V., (ed.), 2018, Collective Redress Mechanisms in Consumer Protection 
austrijski Konsumentenschutzgesetz ni italijanski Codice del consumo ne sadrže definiciju kolektivnog interesa potrošača ${ }^{30}$ ).

Kako odredbe Zakona iz 2010. godine o zaštiti kolektivnih interesa potrošača nisu zaživele u dovoljnoj meri u praksi, a izostanak preciznih normi je doveo do nejasnoća, javila se potreba da se u novom zakonu ove odredbe izmene. Iako je zakonodavac imao mogućnost da izmenom zakona otkloni nedostatke na koje je ukazao Ustavni sud, Zakonom o pravima potrošača iz 2014. godine uvedeno je rešenje prema kojem je zaštita kolektivnih interesa potrošača poverena organima uprave, što je relativno retko u uporednom pravu evropskih zemalja. Tako (član 146. stav 5): „U postupku zaštite kolektivnog interesa primenjuju se pravila opšteg upravnog postupka, ako ovim zakonom nije drugačije propisano." Prema ovom rešenju, nadležni organ uprave ovlašćen je da pokrene postupak u kome procenjuje da li je došlo do povrede kolektivnog interesa potrošača. Ministarstvo ima mogućnost da ovaj postupak pokrene na zahtev ovlašćenih predlagača ili po sopstvenoj inicijativi. Organizacije potrošača, uzevši u obzir njihovu ulogu, zakonom su određene kao primarni institut za podnošenje predloga za ocenu postojanja kolektivne povrede prava potrošača. Međutim, važnu ulogu mogu i moraju imati i inspekcijske službe, s obzirom na to da su prepoznate od strane potrošača kao prvi organ kome se obraćaju u slučaju povrede prava, kao i u kasnijem nadzoru nad poštovanjem izrečene mere. ${ }^{31}$

Međutim, teško je precizno oceniti koje od ova dva rešenja efikasnije ostvaruje zaštitu kolektivnih interesa potrošača. $S$ jedne strane, zaštiti potrošača koje je predviđao Zakon iz 2010. godine nedostajala je podrška organizacija civilnog društva, kao i druga tela koja bi imala aktivnu legitimaciju da potrošačima pruže neophodnu podršku u pokretanju i vođenju sudskog postupka. ${ }^{32} \mathrm{~S}$ druge strane, ni rešenje koje predviđa Zakon iz 2014. godine nije zaživelo u praksi, pre svega zbog neadekvatnog institucionalnog kapaciteta sektora za zaštitu potrošača nadležnog ministarstva (trgovine, turizma i telekomunikacija).

\section{EVROPSKI STANDARDI ZAŠTITE POTROŠAČA U KONTEKSTU INTEGRACIJE SRBIJE U EVROPSKOJ UNIJI}

Shodno opredeljenosti za članstvo u Evropskoj uniji, Srbija je sa ciljem dostizanja višeg nivoa zaštite potrošača svoje zakonodavstvo unapređivala u skladu sa direktivama, preporukama i trendovima Evropske unije.

Prema Izveštaju o skriningu od 15. juna 2016. godine za pregovaračko poglavlje 28 - Zaštita potrošača i zdravlja, ustanovljeno je da je Srbija dostigla zadovolja-

in the European Union and South East Europe: Comparative Study, Skoplje, Deutsche Gesellschaft für Internationale Zusammenarbeit - GIZ, p. 340

30 Babović, B., 2014, Zaštita kolektivnih interesa potrošača, Anali Pravnog fakulteta Univerziteta u Beogradu, 2.

31 Uporedi: YUCOM, 2019, Vodič za zaštitu prava potrošača, Beograd, str. 15-25. Takođe: Matić, M., 2013.

32 Bergh, R. van den, Visscher, L., 2008, The Preventive Function of Collective Actions for Damages in Consumer Law, Erasmus Law Review, Vol. 1, No. 2, p. 10. 
vajući nivo usklađenosti sa pravnim tekovinama u oblasti zaštite potrošača, ali da primena prava i potrošačkih politika treba još da se unaprede. ${ }^{33}$ Ovde se posebno ističe saradnja resornog ministarstva sa organizacijama i jačanje potrošačkih organizacija i NVO kako bi se podigla svest javnosti. Dodatno, izveštaji Evropske komisije o napretku koji iz godine u godinu ističu da Srbija naročito treba da ojača administrativni kapacitet nadležnih organa za zaštitu potrošača i tržišni nadzor, nesumnjivo ukazuju na probleme sistema zaštite, i samo su još jedan dokaz da je primena pravila i svest javnosti na daleko nižem nivou od ocene samog Zakona. ${ }^{34}$ Kao ilustracija situacije može se navesti slučaj koji je na svom internet portalu nedavno registrovala nevladina organizacija potrošača „Efektiva“. ${ }^{35}$

\section{ZAŠTITA POTROŠAČA U PRAKSI}

\subsection{SEKTOR ZA ZAŠTITU POTROŠAČA MINISTARSTVA TRGOVINE, TURIZMA I TELEKOMUNIKACIJA}

Kada je reč o institucionalnom okviru, celokupnu odgovornost za opštu zaštitu potrošača snosi Ministarstvo trgovine, turizma i telekomunikacija i njegov Sektor za zaštitu potrošača. ${ }^{36}$ Sektor tržišne inspekcije odgovoran je za opšti nadzor i prevenciju nelojalne konkurencije i za zaštitu potrošača. ${ }^{37} \mathrm{~S}$ tim u vezi, treba istaći da zaštita potrošača, sa jedne strane, zavisi od kapaciteta administrativne infrastrukture kojoj je povereno sprovođenja zakona, ali i od odgovarajućeg nadzora nad tržištem, sa druge. ${ }^{38}$

33 BOŠ, portal „Eupregovori.bos.rs“, 2016, Izveštaj o skriningu, Poglavlje 28 - Zaštita potrošača i zaštita zdravlja, str. 13, (https://eupregovori.bos.rs). Takođe: Evropska komisija, Republika Srbija Izveštaj za 2019. godinu, SWD(2019) 219, 29. 5. 2019.

34 Izveštaji Evropske komisije o napretku Srbije dostupni su na veb-stranici Ministarstva za evropske integracije (www.mei.gov.rs).

35 Ko štiti potrošače? Ili, kako Tržišna inspekcija, svojim nečinjenjem, pogoduje nepoštenoj poslovnoj praksi trgovaca, direktno na štetu potrošača? Sredinom novembra prošle godine, na adresu Tržišne inspekcije smo uputili inicijativu za pokretanje prekršajnog postupka protiv 4 trgovca elektronskim telekomunikacionim uslugama, zbog toga što nisu postupili prema donetim rešenjima Ministarstva trgovine, kojima im je naloženo da prestanu sa ugovaranjem nepravičnih ugovornih odredbi. [...] Ubrzo potom, od Tržišne inspekcije dobijamo odgovor, koji je u najmanju ruku skandalozan, a u kom nam se negativno odgovara za nešto što nismo ni tražili. Dakle, iako smo tražili da Tržišna inspekcija postupi prema već donetim rešenjima Ministarstva trgovine, u kojima je utvrđeno da pomenuti trgovci (VIP, MTS, SBB i Telenor) ugovaraju nepravične ugovorne odredbe na štetu potrošača, i u kojima im je naloženo da istu radnju obustave, dobijamo odgovor u kom nas Tržišna inspekcija upućuje na pokretanje novog postupka za zaštitu kolektivnih interesa potrošača!? (http://efektiva.rs/aktuelnosti-efektiva/potrosaci-aktuelnosti/ko-stiti-potrosace/).

36 Prema sajtu Ministarstva trgovine, turizma i telekomunikacija: „U Sektoru tržišne inspekcije obavljaju se poslovi koji se odnose na: [...] zaštita potrošača [...] priprema nacrta mišljenja i odgovora iz nadležnosti tržišne inspekcije po zahtevu privrednih subjekata, građana, državnih organa i organizacija, organizacija potrošača i dr." (https://mtt.gov.rs/sektori/sektor-trzisne-inspekcije/?0=lat).

37 BOŠ, portal „Eupregovori.bos.rs“, 2016, Izveštaj o skriningu, Poglavlje 28 - Zaštita potrošača i zaštita zdravlja, str. 3, (https://eupregovori.bos.rs).

38 Matić, M., 2013, str. 5. 
Ministarstvo je nadležno za kolektivnu zaštitu interesa potrošača, koju sprovodi kroz upravni postupak u kome utvrđuje određeno poslovanje koje spada u nedozvoljene radnje trgovca koje pogađaju određenu grupu potrošača, označavajući takvo ponašanje kao povredu interesa uz izricanje upravne mere. Ovim oblikom postupanja treba da se postigne efekat nekadašnje kolektivne tužbe, s tim da su kao prednost za sprovođenje ovog postupka kroz upravni postupak u odnosu na parnični navedene efikasnost i ekonomičnost. Prema tome, jednom utvrđeno ponašanje trgovca kao povreda kolektivnog interesa deluje ka svim potrošačima, te se u slučaju ponavljanja takve prakse potrošači „priključuju“ već utvrđenoj povredi koja se sada direktno sankcioniše uz pomoć inspekcijskog nadzora bez potrebe da se u konkretnom slučaju ispituje. Međutim, praksa pokazuje da se potrošači i pored ustanovljene povrede kolektivnog interesa opet upućuju na upravni postupak, čime se kolektivna zaštita obesmišljava i izjednačuje sa individualnom. Upravo ovakvo postupanje organa uprave govori o nedovoljnom institucionalnom kapacitetu, a pre svega neprepoznavanju kolektivnog interesa potrošača.

Pravilna i dosledna primena instituta kolektivne zaštite uz inspekcijski nadzor mogla bi obezbediti zakonitost poslovanja i sprečiti štetne posledice po potrošače. Pojačana vidljivost organizacija za zaštitu potrošača i preventivno delovanje u vršenju inspekcijskog nadzora, postupanje Ministarstva u slučaju sumnje na povredu kolektivnog interesa, te naknadni nadzor inspekcije, mogu obezbediti visok stepen kontrole i izvršiti jak uticaj na ponašanje trgovaca.

\subsection{STUDIJA PRIMERA NA SLUČAJU SUPERNOVA}

Da li je i u kojoj meri upravni postupak zaštite potrošača dao rezultate možemo sagledati kroz praksu pomenutih organa i organizacija u slučaju Supernove. Ovaj slučaj postao je vidljiv zahvaljujući organizaciji za zaštitu potrošača „Efektiva“"39. Supernova je preduzeće - pružalac usluga elektronskih komunikacija (čiji su sadržaj TV kanali) koje, prema Zakonu o zaštiti potrošača (čl. 83-92), spadaju u usluge od opšteg ekonomskog interesa. ${ }^{40}$ Potrošači, u ovom slučaju pretplatnici, nakon što je ovaj operator promenio specifikacije usluga, zatražili su raskid ugovora usled bitno promenjenih uslova pod kojim su zaključili ugovor, bez otkaznog roka i nadoknade. ${ }^{41}$ Kao otkazni razlog, pretplatnici su naveli da je operator ukinuo veći broj kanala, te da nisu obavešteni mesec dana una-

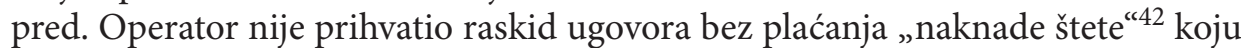
predstavlja kao iznos preostalih rata do isteka minimalnog trajanja ugovora. $\mathrm{Na}$ osnovu člana 107. Zakona o elektronskim komunikacijama koji definiše izmenu uslova ugovora, i prava i obaveze operatora i pretplatnika, ${ }^{43}$ pretplatnici su upu-

39 Efektiva portal, (http://efektiva.rs/).

40 Supernova portal, (www.mojasupernova.rs/).

41 Efektiva portal, Sukob operatora preko leđa potrošača!, (http://efektiva.rs/aktuelnosti-efektiva/ potrosaci-aktuelnosti/sukob-operatora-preko-leda-potrosaca/).

42 U odgovorima operatora ističe se da sadržaj paketa ne obuhvata programsku šemu, te da ne predstavlja osnov za raskid ugovora.

43 Zakon o elektronskim komunikacijama, Sl. glasnik RS, br. 44/10, 62/14, 95/18, član 107: „Operator je dužan da pretplatnika, najmanje mesec dana unapred, obavesti na pogodan na- 
tili prigovore i obratili se organizacijama za zaštitu potrošača, RATEL-u, Tržišnoj inspekciji i Ministarstvu trgovine, turizma i telekomunikacija. Rezultat obraćanja potrošača u slučaju Supernova je sledeći: ${ }^{44}$

- Sektor za zaštitu potrošača pri Ministarstvu trgovine, turizma i telekomunikacija poučio je podnosioce da mogu uputiti prijavu tržišnoj inspekciji ukoliko trgovac, odnosno operator ne postupa u skladu sa navedenim odredbama, dok se o navodima potrošača nije izjasnio.

- Regulatorna agencija za elektronske komunikacije i poštanske usluge (dalje u tekstu: RATEL) u svom odgovoru oštećenim potrošačima utvrdila je da, osim što obaveštenje operatora nije istaknuto u zakonom propisanom roku, isto ne sadrži ni pouku o pravu pretplatnika na raskid ugovora u skladu sa posebnim pravilnikom. ${ }^{45}$ Osim detaljne analize propisa i zauzimanja stava po pitanju prava korisnika usluga, RATEL je uputio prijavu inspekcijskim službama, nadležnim sektorima Ministarstva trgovine, turizma i telekomunikacija, gde naglašava da se radi o zaštiti kolektivnog interesa potrošača s obzirom na broj pretplatnika. ${ }^{46}$

- Tržišna inspekcija izvršila je nadzor pokrenut po prijavama potrošača gde je konstatovala povredu člana 89 . Zakona o zaštiti potrošača i napomenula da će biti pokrenut prekršajni postupak. ${ }^{47}$

- Nakon reagovanja svih pomenutih organa uprave, Sektor za zaštitu prava potrošača pri nadležnom ministarstvu donosi rešenje kojim utvrđuje da operator postupa suprotno članu 89. Zakona o zaštiti potrošača i upućuje pretplatnike da u poslovnicama operatora podnesu zahtev za raskid ugovora koji ne sme biti uslovljen naknadom štete. Na kraju, pretplatnike obaveštavaju da je eventualno naknadno nepostupanje u pojedinačnim slučajevima u nadležnosti inspekcije.

Da bismo govorili o zaštiti prava potrošača kao vrednosti i cilju koje potrošačko zakonodavstvo teži da ostvari, moramo sagledati i aspekt koji je širi od zaštite u upravnom postupku. Međutim, sagledavajući praksu upravnih organa možemo donekle dati odgovor na pitanje da li je obezbeđena delotvornost i efikasnost postupanja. Delotvornost i efikasnost postupanja pre svega bi rezultovala u prestanku javljanja dalje povrede kolektivnog interesa potrošača kod konkretnog trgovca na koga se upravni akt odnosi, ali i kod svih drugih trgovaca koji

čin o nameri jednostrane izmene uslova ugovora, kao i pravu pretplatnika na raskid ugovora pre isteka perioda na koji je zaključen. Pretplatnik ima pravo da, po prijemu obaveštenja iz stava 1. ovog člana, raskine ugovor bez obaveze plaćanja troškova u vezi sa raskidom, ako se najavljenim jednostranim izmenama bitno menjaju uslovi pod kojima je ugovor zaključen, na način koji nije na korist pretplatnika, a naročito u pogledu specifikacije usluga (sadržaj paketa) i uslova za korišćenje usluga u vezi sa ponuđenim promotivnim pogodnostima."

44 Efektiva portal, Sukob operatora preko leđa potrošača! (http://efektiva.rs/aktuelnosti-efektiva/ potrosaci-aktuelnosti/sukob-operatora-preko-leda-potrosaca/).

45 Pravilnik o opštim uslovima za obavljanje delatnosti elektronskih komunikacija po režimu opšteg ovlašćenja, Sl. glasnik RS, br. 58/18.

46 RATEL, Odgovor na prigovor (1-02-341-42/20-10 od 10. 3. 2020).

47 Sektor tržišne inspekcije, Ministarstvo trgovine, turizma i telekomunikacija, Obaveštenje (334-00-2845/2020-06 od 25. 3. 2020). 
primenjuju istu praksu (npr. SBB i PostNet), kroz uticaj preventivne ulogu ovakve mere. $U$ tom smislu, dalji inspekcijski nadzor i potrošački prigovori mogu biti indikator pomenute delotvornosti i efikasnosti.

Međutim, nepunih mesec dana nakon utvrđenog poslovanja Supernove, kojim se povređuje pravo potrošača na raskid ugovora bez naknade, organizacija „Efektiva“ koja se bavi zaštitom potrošača izašla je sa saopštenjem da je nedozvoljena praksa operatora Supernova u vidu naplate „štete“ nastavljena. ${ }^{48}$ Ovakva neželjena praksa operatora, koja se ponavlja i nakon upravnog i prekršajnog postupka, ukazuje na neadekvatno sankcionisanje takvog poslovanja - visinu zaprećene kazne i izvesnost kažnjavanja, time i motivisanje trgovaca da sa takvom praksom i nastave.

\section{ZAKLJUČAK}

Donošenje Zakona o zaštiti potrošača 2014. godine vodilo je boljem položaju potrošača kroz uvođenje novih instituta, jačanju položaja organizacija za zaštitu potrošača i dr. Tako postavljen zakonodavni okvir nesumnjivo prati evropsko zakonodavstvo, koje je u razvoju potrošačkog prava dostiglo visok stepen, o čemu svedoče izveštaji Evropske komisije o napretku Srbije već nekoliko godina unazad. Međutim, isti izveštaji, a i praksa, ukazuju da zaštita potrošača na kraju zavisi od razvoja administrativne infrastrukture radi obezbeđenja nadzora nad tržištem i sprovođenja zakona u ovoj oblasti. Pored toga, od 2014. godine Srbija pravi značajno odstupanje od većine evropskih zemalja uvođenjem kolektivne zaštite potrošača u upravni postupak, umesto u građanskopravni postupak, navodeći efikasnost i ekonomičnost kao prednost. Na primeru Supernove uočavamo da kolektivna zaštita u upravnom postupku vodi neprepoznavanju povrede kolektivnog interesa potrošača od strane institucija, neujednačenoj praksi u skoro identičnim slučajevima i nedoslednosti primene donetih akata. Pored toga, uvidom u odluke nadležnog ministarstva o povredi kolektivnog interesa potrošača donetih u proteklih šest godina koliko je prošlo od uvođenja ovog instituta zaštite u upravnom postupku, primećujemo da se većina odluka odnosi na telekomunikacione operatore sa nalogom da se otklone nepravilnosti, prekine sa nepoštenom poslovnom praksom, odnosno ugovaranjem nepravičnih ugovornih odredaba ubuduće. Od toga, jedan broj odluka odnosi se na pokušaj naplate štete pri jednostranom raskidu ugovora od strane potrošača, gde je ova praksa utvrđena i označena kao povreda kolektivnog interesa. Odluke nadležnog ministarstva nisu uspele da odvrate operatore od takve prakse, delom zbog kaznene politike koja evidentno nije odgovarajuća ekonomskoj snazi trgovca, a delom zbog neadekvatnog nepostupanja inspekcijskih službi.

48 Operator je raskidao ugovore sa pretplatnicima koji su upućivani od strane upravnih organa putem obrasca koji sadrži sledeću odredbu: „Potpisivanjem ovog zahteva Korisnik potvrđuje da je upoznat sa odredbom Opštih uslova koja se odnosi na otkazni rok od 30 dana od dana podnošenja ovog zahteva, kao i o uslovima za naknadu štete ukoliko se zahtev podnosi u toku minimalnog perioda korišćenja usluge." Pored toga, prijavljena je i praksa slanja računa nakon raskida ugovora čiji iznos predstavlja još jedan pokušaj naplate spornih ukupnih (budućih) mesečnih iznosa. 
Ovako postavljena zakonodavna rešenja i postojeća praksa dovode do zaključka da zakonom predviđena zaštita kolektivnog interesa potrošača u upravnom postupku nije suštinski dovela do kolektivne zaštite prava potrošača, već usmerava potrošača na individualne postupke zaštite. Kolektivna zaštita potrošača, preneta iz nadležnosti suda na organe uprave, pokazala je da organi uprave nemaju kapacitete da odgovore na ovaj zadatak.

\section{LITERATURA}

1. Babović, B., 2014, Zaštita kolektivnih interesa potrošača, Anali Pravnog fakulteta Univerziteta u Beogradu, 2.

2. Bergh, R. van den, Visscher, L., 2008, The Preventive Function of Collective Actions for Damages in Consumer Law, Erasmus Law Review, Vol. 1, No. 2.

3. Blažić, Đ., 1996, Inspekcijski nadzor kao oblik upravno pravne zaštite građana, Pravni život, 9.

4. Blažić, Đ., 1995, Prilog teoriji o inspekcijskom nadzoru, Pravni život, 9.

5. Bodiroga, N., 2013, Komentar Odluke Ustavnog suda IUz-51/2012 o neustavnosti glave 36. Zakona o parničnom postupku: Postupak za zaštitu kolektivnih prava i interesa proglašen neustavnim i time onemogućeno udruženjima ostvarivanje prava na pristup sudu, Beograd, Ustavno-sudski informator, 2014/1.

6. Božović, B., 2016, Stručna analiza Zaštita potrošača u evropskom pravu i u praksi međunarodnih i nacionalnih sudova, Podgorica, Centar za monitoring i istraživanje.

7. Dimitrijević, P., 1983, Osnovi upravnog prava, Beograd.

8. Jovanovic-Zattila, M., Vukadinovic, R., Collective Redress in Consumer Protection in Serbia, in: Efremova V., (ed.), 2018, Collective Redress Mechanisms in Consumer Protection in the European Union and South East Europe: Comparative Study, Skoplje, Deutsche Gesellschaft für Internationale Zusammenarbeit - GIZ.

9. Karanikić Mirić, M., 2014, Kolektivna zaštita potrošača u srpskom pravu, Zbornik radova Perspektive implementacije evropskih standarda u pravni sistem Srbije, Knjiga 4, Beograd, Pravni fakultet Univerziteta u Beogradu.

10. Lazarević, N. et al., 2013, Studija potrošačke politike u Srbiji ka evropskom nivou zaštite potrošača u Srbiji, Beograd, Centar za evropske politike.

11. Lilić, S., Manojlović, A., Golubović, K., 2018, Priručnik za praktičnu primenu novog ZUP-a - Sporna pitanja i odgovori, Beograd, Službeni glasnik.

12. Lilić, S., 2014, Upravno pravo / Upravno procesno pravo, 8. izdanje, Beograd, Pravni fakultet Univerziteta u Beogradu.

13. Lilić, S., 2019, Zakon o opštem upravnom postupku - Anatomija zakonskog projekta, Beograd, Dosije.

14. Madžar, L., 2010, Politika zaštite potrošača u Srbiji sa aspekta politike zaštite potrošača u zemljama EU, Škola biznisa, 4.

15. Matić, M., 2013, Analiza zakona o zaštiti potrošača, Beograd, EU Support to the Office for Cooperation with Civil Society. 


\section{PROPISI}

1. Zakon o državnoj upravi, Sl. glasnik RS, br. 79/05, 101/07, 95/10, 99/14, 47/18, 30/18.

2. Zakon o elektronskim komunikacijama, Sl. glasnik RS, br. 44/10, 62/14 i 95/18.

3. Zakon o inspekcijskom nadzoru, Sl. glasnik RS, br. 36/15, 44/18, 95/18.

4. Zakon o ministarstvima, Sl. glasnik RS, br. 44/14, 14/15, 54/15, 96/15, 62/17.

5. Zakon o opštem upravnom postupku, Sl. glasnik RS, br. 18/16, 95/18.

6. Zakon o opštem upravnom postupku, Sl. list SRJ, br. 33/97, 31/01; Službeni glasnik RS, br. 30/2010.

7. Zakon o zaštiti potrošača, Sl. glasnik RS, br. 62/14, 6/16, 44/18.

8. Zakon o zaštiti potrošača, Sl. glasnik RS, br. 73/10.

9. Zakon o zaštiti potrošača, Sl. glasnik RS, br. 79/05.

10. Zakon o zaštiti potrošača, Sl. list SRJ, br. 37/02.11. Pravilnik o opštim uslovima za obavljanje delatnosti elektronskih komunikacija po režimu opšteg ovlašćenja, Sl. glasnik $R S$, br. 58/18.

11. UN General Assembly, Consumer protection: resolution / adopted by the General Assembly, 16 April 1985, doc A/RES/39/248.

12. Ustav Republike Srbije, Sl. glasnik RS, br. 98/06.

\section{IZVORI SA INTERNETA}

1. BOŠ, portal „Eupregovori.bos.rs“, 2016, Izveštaj o skriningu, Poglavlje 28 - Zaštita potrošača i zaštita zdravlja, (https://eupregovori.bos.rs).

2. Commission of the European Communities, Consumer Protection and Information Policy - Third Report, 1980, (http://aei.pitt.edu/3103/1/3103.pdf).

3. Efektiva portal, Sukob operatora preko leđa potrošača!, (http://efektiva.rs).

4. Ministarstvo trgovine, turizma i telekomunikacija, Sektor tržišne inspekcije, (https:// mtt.gov.rs/sektori/sektor-trzisne-inspekcije/?0=lat).

5. Ministarstvo za evropske integracije, (www.mei.gov.rs).

6. Nacionalna organizacija potrošača Srbije, 2018, Vodič kroz kolektivnu zaštitu.

7. YUCOM, 2019, Vodič za zaštitu prava potrošača. 


\title{
INSPECTION SUPERVISION AND COLLECTIVE CONSUMER PROTECTION IN ADMINISTRATIVE PROCEDURE - THE SUPERNOVA CASE STUDY
}

\author{
Stevan Lilić
}

Katarina Toskić

\section{SUMMARY}

Consumer protection in Serbia became a constitutional category in 2006, and the subsequent consumer protection laws introduced new institutes and regulated this in accordance with European standards. However, the problems that arise when applying individual protection mechanisms in the consumer context are an extremely large number of transactions of relatively small value, i.e. the value of an individual injured interest is usually so small that, from the consumer's point of view, this value does not justify legal proceedings as it lasts too long and costs a lot. Different mechanisms for the protection of collective consumer rights and interests represent the answer to the mentioned problem. European legislation saw the solution in a collective lawsuit, which proved to be effective through the practice of European countries. However, with the introduction of collective consumer protection in administrative proceedings following the 2013 decision of the Constitutional Court declaring collective redress in consumer disputes before the court unconstitutional, Serbia is making a significant departure. The Supernova case indicates that collective consumer protection in administrative proceedings leads to non-recognition of the violation of the collective interest of consumers by institutions, uneven practice in almost identical cases and inconsistency in the application of adopted acts. Collective consumer protection, transferred from the jurisdiction of the court to the administrative bodies, has shown that they do not have the capacity to respond to this task.

Key words: administrative control, inspection procedure, consumer protection, collective consumer protection, the Supernova case. 